\section{Texto, contexto e hipertexto: três condições da linguagem, três condições da mente}

\section{RESUMO}

Este artigo trata da questão das tecnologias e sua relação com a linguagem através da evolução do homem em distintas épocas.

\section{ABSTRACT}

This paper deals with technologies and their relationship with language along the evolution of mankind in different epochs.

\section{PALAVRAS-CHAVE (KEY WORDS)}

- Tecnologias (Technologies)

- Linguagem (Language)

- Mente (Mind)

\section{Derrick de Kerckhove}

Universidade de Toronto - Canadá
As teCnologias QUE sustentam ou gerenciam a linguagem também afetam a mente, por necessidade, simplesmente porque a linguagem é um sistema para a articulação da mente, um tipo de sistema operacional amplamente editado. Deste modo, a linguagem possui uma relação próxima e íntima com nossa mais interna sensibilidade e também com o conteúdo e com a estrutura de nossas mentes, como mostramos nesse artigo. Por exemplo, as sociedades orais possuíam muito menos suporte de memória verbal e eram mais ou menos obrigadas a viver em um mundo no qual o corpo tinha que fazer o trabalho de lembrar e eles tinham que continuar a reforçar o passado.

Duas grandes tecnologias modificaram nossos primeiros relacionamentos com a linguagem: a escrita e a eletricidade. A escrita através da separação entre texto e contexto e também através do isolamento do leitor e da liberação das mentes individuais de uma mente única e coletiva que era a mente das tribos. A eletricidade traz todos os sentidos de volta para a linguagem, mas, ao mesmo tempo, ela externa as mentes dos leitores na tela e torna mais uma vez públicos os conteúdos e os traumas da mente privada da escrita.

Com a ajuda da teoria dos objetos mentais de Jean-Pierre Changeux, tentaremos estreitar algumas características da mente hipertextual, a partir de comparações entre objetos mentais e digitais. O próximo passo tecnológicológico que está nas TIs (Tecnologias da Inteligência), depois do "wirelessness" (sem cabos), é a "mente-máquina-conectada- 
diretamente", onde a principal interface de tempo real é a mente humana. Com a convergência cada vez mais forte entre oralidade (tempo real), escrita (bases de dados e todos os arquivos) e eletricidade (todas as coisas digitais), podemos esperar um aumento gigantesco da mente.

Existem mesmo três estágios principais da linguagem, conforme sabemos, oral, escrita e eletrônica. A principal interface entre o eu e o mundo na sociedade oral é o corpo físico. O corpo inteiro fala, o corpo inteiro lembra, os corpos de todos fazem parte do corpo político. Por razões óbvias, a sociedade oral é a sociedade do contexto, não do texto. As pessoas estão sempre em contexto, elas vivem em uma espécie de presente prolongado, contudo, elas referem-se a eventos que aconteceram no passado. Elas reverenciavam os seus ancestrais que Ihes mostraram as regras operacionais da sua principal referência, Deus (ou deuses), o ur-contexto. Essas sociedades eram "religiosas" quase que por necessidade, não por escolha. A sobrevivência delas dependia da experiência compartilhada. Este é o contexto. Para manter o contexto vivo, elas o ritualizavam e o reforçavam, que é uma forma encontrada para a coletividade lembrar. Elas não estudavam o passado, simplesmente o tornavam presente. É uma sociedade que é perceptivamente dominante no sentido que os seus membros confiam nos seus sentidos (sensoriais) mais do que no sentido puro (significado) para que a realidade possua sentido. Mesmo a sua memória é ancorada em modalidades sensoriais, estátuas, monumentos, canções, contar estórias, atuações.

As sociedades da escrita utilizam uma ferramenta para armazenar a linguagem. Essa ferramenta ajuda as pessoas a transformar o contexto em texto, a separar o texto do contexto, conseqüentemente a separar eles mesmos do contexto. Quanto mais confiável e simples é a ferramenta, mais fácil é separar o texto do contexto e recolocá-lo em outros contextos (a origem da ficção, é claro, mas também a origem da maior parte das tecnologias). $\mathrm{O}$ material impresso é a interface dominante da sociedade da escrita. O que é escrito/ impresso/lido não constitui toda linguagem, são apenas cuidadosas seleções de linguagem, então o que é impresso toma a sua posição em uma certa ordem de prioridade, em qualquer nível, em qualquer gênero e em quaisquer categorias. Livros e papéis propõem amplamente às pessoas os conteúdos de "realidade" filtrados através da modalidade do texto. Para um leitor, nas culturas alfabetizadas, a linguagem primeiro aparece como uma corda abstrata de signos facilmente reconhecíveis, depois como uma construção mental, uma espécie de "memória assistida". Ao contrário das sociedades orais, as sociedades do texto não se preocupam em perder o passado, elas apenas o arquivam. Então a sua propulsão é para o futuro. É sempre um avanço, um salto ser melhor do que o passado, com todas as maravilhosas tecnologias que continuam "desaguando". Elas não são muito religiosas e nem sempre precisam dos outros para se desenvolver. Elas são mais ou menos pessoas que se fazem por si mesmas.

A eletricidade, desde o tempo do telégrafo, formatou a linguagem, transformou-a em ubíqua, instantânea e, agora, em digital. Através da tradução de toda experiência, incluindo as sensoriais, em uma mesma substância simplificada, a digitalização permite que as experiências retornem às tecnologias da troca lingüística. É isto que significa multi ou hipermídia (visão, audição), realidade virtual (sinestesia), sistemas interativos (tato). O que Walter Ong nomeou "oralidade secundária" é, na verdade, o resultado da eletrificação da linguagem. Quer estejamos assistindo à televisão ou surfando na web, estamos vendo transposições multissensoriais da linguagem, com uma alta ênfase na iconicidade. A mente do hipertexto é dominada por ícones, 
logotipos, links. Sua principal interface é a tela. O hipertexto não implica simplesmente "um texto que está ligado a outros textos", ele realmente circunda todo o mundo da comunicação eletrônica em um processo de armazenamento permanente de informação. Ao mesmo tempo, o hipertexto introduz as mentes dos usuários às telas, interconectando-os e os acelerando em redes. Qualquer um que esteja on-line é, de fato, parte de um hipertexto mundial.

A questão-chave é a da forma da mente do hipertexto. Ela é similar àquela do contexto, mas não absolutamente coletiva, uma vez que ela opera em tempo real (e também fora de sincronia em relação ao tempo) com e através de endereços específicos. É quase como a mente do texto, mas é invertida, exteriormente orientada para a tela em vez de interiormente orientada para a psique privada. A mente do hipertexto compartilha das mentes do texto e do contexto. Tem um pouco de cada uma e mais. É conectiva. Isto significa que, enquanto a memória coletiva está mais ou menos disponível em bancos de dados e on-line, o portal de cada um de nós é privilegiado, nossa navegação única e nossa experiência são partilhadas apenas ao nível em que a permitimos. Na verdade, podemos dizer que a mente oral também é compartilhada. Sim, mas é o único tipo disponível, a mente privada sendo incluída ao pensamento e à fala comuns. É bem provável que a intolerância encontrada em muitos grupos fundamentalistas seja mais constitucional do que uma intenção racional. A mente elétrica é verdadeiramente pós-escrita no sentido que pode dar-se ao luxo de conhecer sobre si própria e sobre a mente escrita, ela pode combinar o privado e o coletivo em uma única entidade, a conectiva, sem ameaçar uma à outra.

O coletivo, o privado e o conectivo favorecem diferentes formas de processos de pensamento sem excluírem completamente um ao outro. A forma dominante de pensamento nas sociedades orais é a fala. Se a palavra "pensamento" é muito ambígua, a substitua por "deliberação". É a deliberação da corte, da palavra, do teatro, da competição retórica, do debate público, da persuasão política, do sermão, do oráculo, da fórmula mágica do doutor. Nós temos sempre admitido que o pensamento era silencioso, uma operação internalizada e privada da mente em isolamento, mas talvez estejamos errados. Sociedades orais pensam em voz alta e juntas. Os princípios de Francisco Varela se aplicam muito bem ao processo de pensamento nas culturas orais:

A fala é uma incorporação da linguagem e pensamento.

A compreensão comum (a mente) emerge do discurso.

Situações orais implicam intersubjetiv idade, que é a co-presença do tempo real dos sujeitos que falam.

Oralidade é caracterizada pela sua permanente condição de circulação. As palavras não possuem local de descanso, são mantidas em circulação permanente (por esta razão requerendo muita repetição e expressões formuladas).

Pessoas da escrita falam silenciosamente em suas cabeças e chamam isso de pensamento, enquanto as sociedades elétricas paradoxalmente "escrevem oralmente". Esse é um tipo de tratamento da linguagem que aparece simultaneamente em contexto e é arquivado ao mesmo tempo. Em uma mente da escrita o acesso à memória é privado e discreto, no entanto é um acesso apenas à memória do sujeito e a mais ninguém. $O$ acesso ao texto pode estar comumente disponível, mas a transformação do texto em pensamento e em imagens é inteiramente privada (que é a razão pela qual, ao contrário da visão popular e acadêmica, os jornais não são "mídia de massa"). Pensamento ou deliberação em condições hipertextuais significa acessar as memórias de todos e compartilhá-las diretamente em tempo real com o capital do conhecimento da condição 
humana. É desnecessário dizer que uma afirmação como essa precisa ser matizada pelo reconhecimento de que as condições políticas e econômicas alteram esse estado ideal.

Entretanto, a cognição hipertextual não é limitada ao único indivíduo acessando a memória coletiva em uma forma conectada. É também uma cognição compartilhada. Os conteúdos de nossas telas estão simultaneamente disponíveis a muitas pessoas ao mesmo tempo, sincronicamente, ou além do tempo, diacronicamente. Os conteúdos das telas e dos bancos de dados podem não ser tão flexíveis ou matizados e complexos quanto aqueles de nossas mentes privadas, mas eles são, constantemente, mais confiáveis, não apenas por repetirem fielmente $o$ que representavam originalmente, mas também por os enriquecerem com novos links e novas adições e exemplificando novas parcerias no pensamento.

O que partilhamos na tela é o equivalente tecnológico do que o neurobiologista francês Jean-Pierre Changeux chama de "objetos mentais" (OM). Os OMs são configurações sinápticas da atividade neuronal que representam ou evocam imagens e idéias ou sons e sensações que o sujeito experimenta, reconhecendo-as como significante, quer no isolamento ou na conexão com outras imagens, idéias, sensações. Para Changeux o principal critério para isto é o nível ao qual o objeto mental irá endereçar os receptores sensoriais, ou respostas estruturalmente embebidas nestas partes do cérebro que são responsáveis por integrar os dados ao sentido. Baseado no nível de conteúdo sensório que diferentes situações de pensamento evocam, Changeux sugere que existam três tipos principais de "gráficos neuronais", ou seja, configurações de conexões sinápticas:

Perceptos: são as imagens que dependem mais do contato direto e em tempo real dos sujeitos com a realidade ambiental na frente ou ao redor deles; possuem um conteúdo altamente sensório e, por isso, eles se endereçam a áreas do cérebro onde esse tipo de dado é processado e também sofre oposições.

Conceitos: esses são as configurações das conexões sinápticas que se referem preferivelmente a padrões, modelos e outras figuras abstratas que são fáceis de misturar e de unir e de interconectá-los entre eles mesmos. Eles são processados em partes diferentes e combinações diferentes de colaborações entre as partes do cérebro.

Ícones (ou "imagens da memória"): estes são feitos de uma mistura das referências sinápticas perceptuais e conceptuais e nos fornecem os itens de lembrança e memória. Tipicamente, por causa do conteúdo sensorial que é evocado e não experimentado e apoiado pela estimulação externa, eles tendem a serem mais fracos (exceto, talvez, em pessoas dotadas de uma imaginação viva ou em leitores experientes de poesia e de novelas).

Quando aplicada aos estudos de mídia e à compreensão de como as tecnologias afetam nossas mentes, é interessante observar que a oralidade claramente favorece relações perceptuais, enquanto a escrita encoraja o predomínio de referências conceituais. As mentes da sociedade de leitores são dominadas por conceitos. Em comparação com a sociedade oral, a sociedade escrita está muda, muito asensorializada e abstrata. O papel dos artistas nas sociedades desse tipo consiste em manter viva a vida sensorial e ainda interessada (música popular e sofisticada, mídia, literatura, etc.). A eletricidade, por outro lado, favorece relações icônicas. Tudo aquilo que vemos numa tela é uma forma de "objeto mental", um ícone, uma imagem da memória, embora externada. Quando a tela comporta a exibição de objetos digitalmente construídos, não podemos deixar de observar as grandes similaridades entre objetos mentais e 
objetos digitais (OD).

Pontos em comum entre os ODs e os OMs:

\section{- Eles dependem de conexões;}

- Eles são recriados sob pedidos, são "justin-time";

- Eles são razoavelmente confiáveis (ODs mais do que os OMs);

- São vulneráveis aos ataques sistêmicos e à destruição (colapsos mentais, viroses);

- Fazem parte de algo maior razoavelmente homogêneo;

- Necessitam de muito pouca energia de intensidade elétrica (orgânica e eletrônica);

- São constituídos de doses variáveis de conteúdo perceptual, icônico e conceitual (wireframes e polígonos são equivalentes típicos dos conceitos de imagem, enquanto renderização é análoga ao trabalho da memória sensorial);

- Possuem escalas e são suscetíveis aos curtos-circuitos e generalizações;

- São feitos para estarem em rede.

Poderíamos continuar por mais um tempo e, se pensássemos mais, provavelmente deveríamos. O valor, entretanto, de alinhar esses pontos de comparação não está em ser exaustivo, mas sim sugestivo das muitas complexidades da mente que são emuladas pelas TIs. É claro que os ODs também adicionam o enorme e expandido potencial de ambos de serem fornecidos por outros além da mente do usuário e por serem agradáveis para co-produção em tempo real por diversos participantes.

Como efeito, as tendências tecnológicas mostram a inexorável corrida em direção a conexões mais rápidas e maiores, assim como em direção a conexões mais pertinentes (hipertinentes como eu as chamo). A rápida melhora dos mecanismos de busca dos primórdios do Yahoo até o tempo presente em que o guru da rede e o Google apresentam progresso cognitivo em saltos e limites. Podemos esperar para breve algo que eu chamo MenteMáquina-Conectada-Diretamente MMCD (Mind-Machine-Direct-Connect MMDC), quando apenas o fato de pensarmos sobre algo na frente de uma tela possibilitará não apenas resgatar algo das profundezas dos bancos de dados do mundo, mas também modificá-lo e compartilhá-lo através de um único pensamento. Em um certo ponto, parecerá que, exceto pela fonte eletrônica ou orgânica, não há muita diferença operativa entre OD e OM. Nesse momento, precisaremos de um pensamento muito disciplinado a fim de não entrar em um mundo que não queremos, pois haverá cada vez menos resistência da matéria ao poder do pensamento amplificado, estendido, simulado e executado pela eletricidade.

Podemos estar bastante certos de que o tipo de sociedade que estamos entrando será diferente daquela do texto e daquela do contexto. Acredito que poderemos esperar uma melhora geral em nossas estratégias colaborativas. Logo, as pessoas descobrirão que, colocando as mentes em séries em vez de em paralelos, obteremos resultados melhores, mais rápidos e mais pertinentes. Um dia, a academia poderá finalmente multiplicar as inteligências e os corações dos seus estudantes em vez de simplesmente dispô-los juntos como eles ainda fazem hoje. A outra coisa é que o software e as interfaces que ainda serão construídas para desenvolver comunidades conectadas são belos. Eles atrairão programação especulativa como uma forma de arte.

As comunidades do hipertexto irão desenvolver tecnologias de software quase biológicos, para além do que hoje chamamos biotecnologia, serão softwares que interagirão tão intimamente em nossa vida cotidiana e em nossos 
modos sensoriais que nós praticamente iremos "vestir o ambiente como nossa pele" como McLuhan teria gostado de dizer e como Steve Mann demonstra de fato em seu trabalho sobre computadores "vestíveis". A saúde crescerá ainda mais na economia geral, mas se estenderá à ecologia, e talvez até mesmo irá substituir muito do militarismo. Isto também encorajará uma maior descentralização, é claro, desde que as tendências presentes continuem distribuindo pelo mundo inteiro as tecnologias sem cabo com custos cada vez mais baixos.

$\mathrm{Na}$ verdade, uma conseqüência política da conectividade será uma transformação gradual do poder da força para o poder da inteligência. E poder da ação também. Numa comunidade conectada propriamente em MMCD em tempo real, com hipertinente e acesso quase automatizado aos bancos de dados mais relevantes, as pessoas podem realmente fazer as coisas acontecerem. $\mathrm{O}$ que queremos saber agora é quais são as prioridades - e responsabilidades - do pensamento e sentimento em uma condição com a qual eles possam ser realizados.

Uma das culturas sobreviventes mais antigas e, de fato, desafiadoras viveu - e que continua viva - sem tecnologia por mais ou menos 50 mil anos em condições de miséria e escassez que mal podem ser comparadas com nenhuma outra. Os aborígenes da Austrália "sonham realidade", eles não apenas a sofrem ou a fazem. Sonhar realidade é uma atividade inteiramente hipertextual. Igualmente, o antigo livro chinês da sabedoria, o I Ching, convida os seus usuários a jogar moedas ou dados para relacionar as suas interrogações às afirmações oraculares que são como o seu horóscopo diário mas, no entanto, mais profundamente racional em sua coerência quase matemática.

Qualquer um brincando com o seu horóscopo diário pratica o pensamento hipertextual sem o saber. $O$ que você faz quando tenta relacionar as predições simplistas endereçadas a você e a todos que nasceram naquele dia ou mês é ligar o texto que você vê na sua frente ao amplo banco de dados que você contém na sua memória. Assim como temos praticado as estratégias cognitivas contextuais e textuais aparentemente por todo o sempre, também temos sido capazes de fazer ligações hipertextuais tanto privada quanto socialmente desde o início dos tempos. O novo fator interessante introduzido pelos amplos poderes expansivos da linguagem multiplicada pela eletricidade é que a tarefa mais urgente que se apresenta aos artistas, cientistas e políticos em um mundo permanentemente à beira de desastres sociais e ecológicos é também a mais antiga: sonhar com um mundo em que queremos viver . 